ресурсами - платформа eFront).

- педагогічний (технології проектного та змішаного навчання).

На основі проектування інформаційно-педагогічних технологій навчання відбувається інтеграційний процес освітньої діяльності ЗППО до відкритої системи, головна перевага якої полягає в тому, що вона одночасно сприяє як підвищенню дієвості освітніх систем, так i зниженню витрат на їх утримання. Відкрите і дистанційне навчання робить освіту максимально мобільною, динамічною і керованою. До основних сучасних проблем, які залишаються перспективою подальших досліджень, віднесемо недостатню розробленість теорії навчання у відкритих педагогічних системах, несформованість іiї поняттєвотермінологічного апарату, готовність науково-педагогічних і педагогічних працівників до роботи у відкритих педагогічних системах.

\title{
Література
}

1. Биков В. Ю. Моделі організаційних систем відкритої освіти: [монографія] / В. Ю. Биков. - Київ : Атіка. 2009. - 684 с. 2. Здіорук С. І. Формування єдиного відкритого освітньо-наукового простору України: оптимальне використання засобів забезпечення випереджального розвитку: аналітична доповідь / С. І. Здіорук, А. Ю. Іщенко, M. М. Карпенко. - $\quad$ Режим доступу : Science_educationl-e2f67.pdf11. $\quad$ 3. Клясен Н. Л. Діяльність закладів післядипломної педагогічної освіти в умовах модернізації освітньої галузі в Україні / Н. Л. Клясен // Післядипломна освіта в Україні. - 2014. - Вип. 2. - С. 10-13.

4. Кухаренко В. Н. Комбинированное (смешанное) обучение [Электронный ресурс] / В. Н. Кухаренко. - Режим доступа : http://kvn-e-learning. blogspot.com/2012/08/blogpost_22.html. 5. Мур Майкл Г. Открытое и дистанционное обучение: тенеденции, политика и стартегии / Майкл Г. Мур, А. Тэйт, П. Реста [и др.]. - Москва : Мзд.ИНТ, 2004. - 139 с. 6. Національна стратегія розвитку освіти в Україні на період до 2021 року [Електронний ресурс]. - Режим доступу : http://www.president.gov.ua/ru/documents/15828.html. 7. Олійник В. В. Освітня діяльність вищих навчальних закладів післядипломної педагогічної освіти: [довідник] / В. В. Олійник, В. О. Гравіт, Л. Л. Ляхоцька [за заг. ред. В. В. Олійника]. НАПН України, Ун-т менедж. освіти. - Донецьк : Донбас, 2012.- 151 с. 8. Чередніченко Г. А. Модель змішаного навчання і її використання у викладанні іноземних мов / Г. А. Чередніченко, Л. Ю. Шапран. - Режим доступу : http://2015. Moodlemoot.in.ua/ course/view.php?id=83\&lang=en. 9. Graham C. R. (2005). Blended learning systems: Definition, current trends, and future directions. In C. J. Bonk \& C. R. Graham (Eds.). Handbook of blended learning: Global perspectives, local designs (pp. 3 - 21). San Francisco, CA : Pfeiffer Publishing.

УДК 621.38

Володимир Макаренко, Віктор Співак

\section{СХЕМОТЕХНІЧНЕ МОДЕЛЮВАННЯ ЯК ЗАСІБ ДЛЯ ПОЯСНЕННЯ ПРОЦЕСІВ, ЩО ВІДБУВАЮТЬСЯ В ЕЛЕКТРИЧНИХ КОЛАХ}

Макаренко В. В., Співак В. М. Схемотехнічне моделювання як засіб для пояснення процесів, що відбуваються в електричних колах.

У статті розглянуто на конкретному прикладі можливість використання програми імітаційного моделювання NI Multisim для пояснення й ілюстрації складних процесів, що відбуваються у радіоелектронних пристроях. Обгрунтовано вибір програми моделювання для аналізу схемотехнічних рішень з точки зору функціональності і вартості їі придбання. 
Обгрунтовується перспективність застосування програм моделювання під час вивчення курсів з електротехніки та радіоелектроніки.

Ключові слова: моделювання, NI Multisim, внутрішній опір, обмежувач напруги, аналіз, дослідження, вимірювання.

Макаренко В. В., Спивак В. М. Схемотехническое моделирование как средство для объяснения процессов, происходящих в электрических цепях.

В статье рассмотрена на конкретном примере возможность использования программы имитационного моделирования NI Multisim для объяснения и иллюстрации сложных процессов, которые происходят в радиоэлектронных устройствах. Обоснован выбор программы моделирования для анализа схемотехнических решений с точки зрения функциональности и стоимости ее приобретение. Обосновывается перспективность применения программ моделирования при изучении курсов электротехники и радиоэлектроники.

Ключевые слова: моделирование, NI Multisim, внутреннее сопротивление, ограничитель напряжения, анализ, исследование, измерение.

Makarenko V. V., Spivak V. M. Circuit simulation as a tool to explain the processes occurring in electrical circuits.

The article describes a specific example of the use of simulation programs NI Multisim to explain and illustrate the complex processes that occur in electronic devices. The choice of the simulation software for the analysis of the circuit design from the point of view of functionality and the cost of its acquisition is grounded. The promising application of simulation programs in the study of electrical engineering and electronics courses is proved.

Ke ywords: simulation, NI Multisim, internal resistance, voltage limiter, analysis, research, measurement.

У більшості студентів під час вивчення дисциплін засвоєння яких потребує розуміння процесів, що відбуваються в електричних колах, виникає проблема повного нерозуміння деяких речей на рівні фізичної інтерпретації результатів роботи як складних, так і дастатньо простих пристроїв.

Наприклад, під час вивчення деяких розділів дисциплін «Цифрова схемотехніка» та «Аналогова схемотехніка» у більшості студентів ефективність роботи пристроїв захисту входів аналогових та цифрових пристроїв ніяк не асоціюється з внутрішнім опором як джерела сигналу, так і джерела опорної напруги, що зумовлює рівень обмеження. Це пояснюється відсутністю практичних навичок роботи 3 електронними схемами у значної більшості студентів. Багаторазові пояснення за допомогою формул та часових діаграм сигналів у різних точках схем майже не дають потрібного результату. Вплив внутрішнього опору джерела сигналу важливо розуміти і під час вивчення інших електронних курсів, де $\epsilon$ елементи схемотехніки. Отже, виникає проблема, яку потрібно розв’язати $з$ мінімальними втратами часу.

Експерименти на фізичних макетах вимагають багато часу і коштів, оскільки потрібно розробити та виготовити макет пристрою чи вузла та провести його експериментальні дослідження. Набагато дешевше та швидше перевірити роботу пристрою, здійснивши моделювання його роботи за допомогою spice-симулятора.

Порівняння програм моделювання функціональними можливостями, об’ємом бази 
моделей та інтерфейсом користувача дозволило з'ясувати, що найбільш зручною в користуванні є NI Multisim компанії National Instruments. Окрім того, починаючи з 2007 року компанія National Instrument щороку випускає безкоштовну версію програми з обмеженими можливостями у співробітництві із провідним світовим виробником електронних компонентів компанією Analog Devices [1, с. 141], а в 2014 р. випущена безкоштовна версія програми (NI Multisim Component Evaluator Mouser Edition) разом з компанією Mouser Electronics [2, c. 25].

Найбільше функціонально повною безкоштовною версією $є$ NI Multisim Analog Devices Edition [1, с. 141], у якій широко представлені як аналогові, так і цифрові компоненти. Обмеження стосуються кількості компонентів схеми що моделюється, яке не повинне перевищувати 25. В останній з випущених безкоштовних версій програми Multisim Blue [2, с. 25] число елементів на схемі може досягати 50. Але навіть 25 компонентів досить для демонстрації функціонування величезної кількості електронних пристроїв.

У всіх наступних безкоштовних версіях програми практично відсутні елементи цифрової техніки, обмежена кількість вимірювальних пристроїв та можливість проведення багатьох видів аналізу, хоча кількість елементів схеми значно збільшилась.

Інтерфейс користувача цієї програми поза конкуренцією. Багатий вибір віртуальних приладів, що детально відтворюють інтерфейси користувача реальних приладів, таких, як багатоканальні цифрові осцилографи, аналізатори спектру, логічні аналізатори та багато інших, дозволяє проводити різноманітні вимірювання у звичному для інженера режимі [1, с. 145]. Наявність тісного зв'язку з програмою NI LabView дозволяє користувачу формувати додаткові вимірювальні пристрої, здійснювати зв'язок 3 реальними вимірювальними пристроями й датчиками, здійснювати керування зовнішніми пристроями.

Можливість проведення великої кількості аналізів дозволяє здійснювати дослідження в широкому діапазоні зміни параметрів елементів та навколишнього середовища. Простий графічний редактор дозволяє досить просто малювати на екрані електронні схеми у звичному зображенні.

Метою статті є демонстрація можливостей використання комп’ютерних програм моделювання для пояснення фізичних явищ, які відбуваються в електричних колах при проходженні через них складних сигналів, та впливу параметрів елементів електричних кіл на характеристики електронних пристроїв.

Для демонстрації можливостей програм моделювання використаємо безкоштовну версію програми NI Multisim Analog Devices Edition. Розглянемо на прикладах роботи обмежувачів напруги вплив на їх роботу внутрішнього опору джерела сигналу та джерел опорної напруги.

Як відомо, обмежувачі напруги використовуються для захисту вхідних кіл аналогових та цифрових пристроїв від перевантаження, яке може призвести до виходу вхідних кіл з ладу або неправильної їх роботи.

На рис. 1 наведено схему двостороннього обмежувача, у якому рівні обмеження задаються джерелами постійної напруги. 

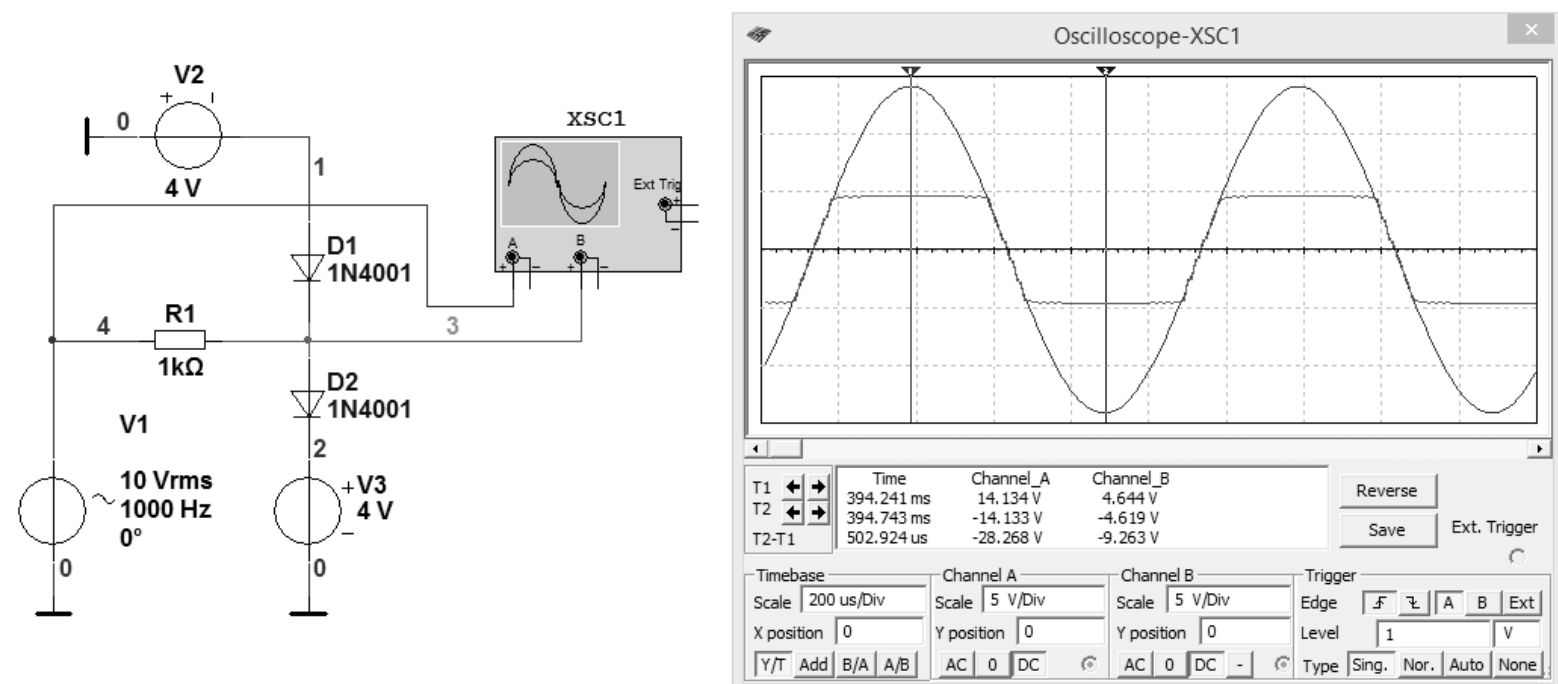

Рис. 1. Схема для дослідження двостороннього обмежувача

На екрані осцилографа XSC1 відображені осцилограми вхідного гармонічного сигналу амплітудою 14,3 В, та обмеженого сигналу, амплітудою 4,6 В. Рівень обмеження зумовлений напругами, що формуються джерелами опорної напруги V2 та V3, та величиною падіння напруги на діодах D1 та D2 (приблизно дорівнює 0,6...0,7 В).

Коли напруга на вході перевищує значення, що дорівнює сумі опорної напруги та падіння напруги на діоді, діод відкривається і через нього починає протікати струм. Якщо позитивна напруга вища, ніж поріг обмеження, то відкривається діод D2, а якщо негативна то діод D1. У результаті цього на резисторі падає напруга, а на виході схеми у точці 3 формується сигнал, амплітуда якого мало залежить від амплітуди вхідного сигналу.

Це пояснюється тим, що напруга джерела V2 та V3 не залежить від струму, що протікає через них, а падіння напруги на діоді мало залежить від струму, що протікає через нього у прямому напрямку (рис. 2). На рис. 2 наведена схема вимірювання вольтамперної характеристики діода (BAX) та ї̈ вид на екрані вимірювача характеристик напівпровідникових пристроїв XIV1.

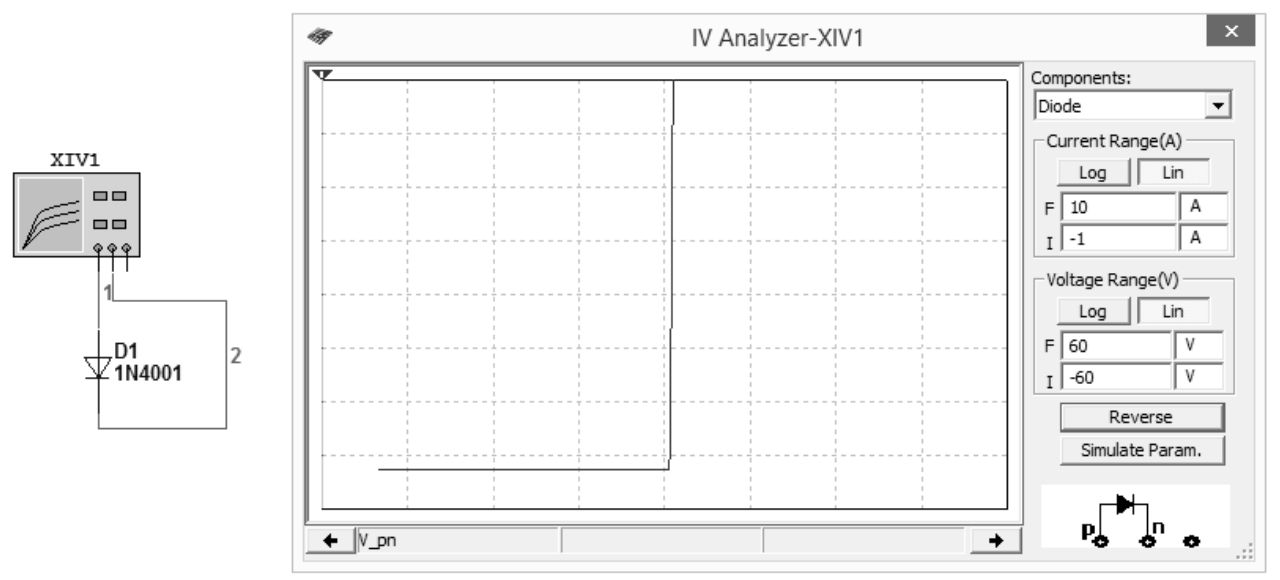

Рис. 2. Схема вимірювання та ВАХ діода 
При детальному дослідженні ВАХ діода можна з'ясувати, що при зміні струму, що протікає у прямому напрямку, у межах від 0,1 до 30 мА, напруга на діоді змінюється від 0,512 до 0,712 В. Отже, використовуючи NI Multisim, можна не тільки продемонструвати роботу схеми, але й виміряти параметри приладів, з яких ця схема формується.

А як впливає внутрішній опір джерела сигналу та величина опору резистора R1 (рис. 1) можна дослідити, змінюючи значення опору R1. При зміні опору від 1 кОм до 10 Ом напруга на виході обмежувача змінюється від 4,6 до 4,9 В, що пояснюється зростанням струму, що протікає через відкриті діоди. Отже, напруга обмеження мало залежить від значення цього опору і його основна функція - обмеження вхідного струму схеми захисту.

Оскільки у практичних схемах, як правило, не використовують окремі джерела живлення для формування опорної напруги, то доводиться використовувати або дільники напруги на резисторах, або параметричні стабілізатори на стабілітронах.

Розглянемо роботу обмежувача за використання резистивних дільників напруги (рис. 3).

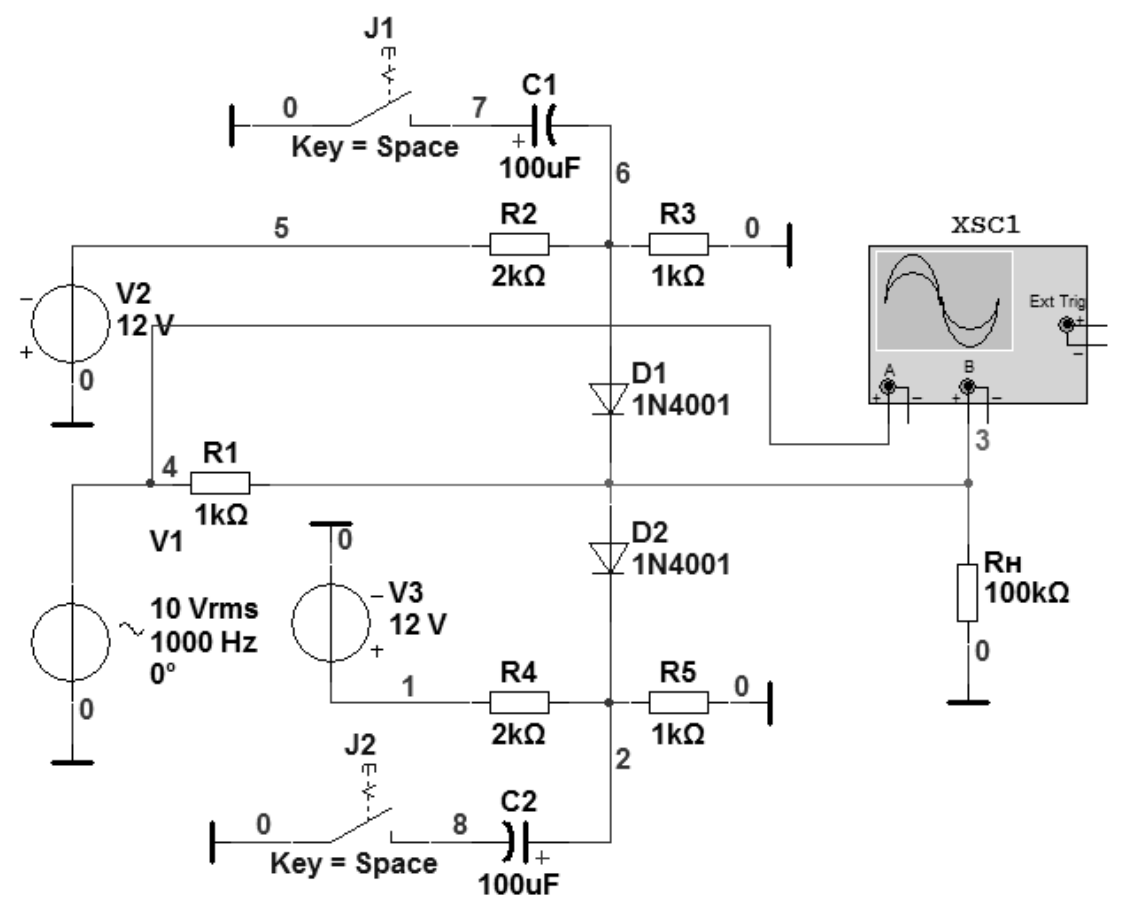

Рис. 3. Схема обмежувача з формуванням опорної напруги за допомогою резистивних дільників напруги

При виборі опору резисторів, з яких складаються дільники напруги виникає дві проблеми. Для того щоб обмежувач працював більш ефективно, необхідно, щоб значення опору R1 було набагато більшим, ніж значення опорів R3 та R5. Це витікає з того, що при відкриванні діода струм, що протікає через ці резистори, утворює спадання напруги на них. Якщо прийняти $R_{1}=R_{3}=R_{5}$, то напруга на виході обмежувача буде складатися 3 постійної напруги, що дорівнює (для позитивної напруги) $U$ пост $=U_{\mathrm{V} 3} \cdot R /\left(R_{4}+R_{5}\right)$, та змінної напруги, що дорівнює $U_{\text {зм }}=U_{\mathrm{V} 1} \cdot\left(R \| R_{5}\right) /\left[R_{1}+\left(R_{4} \| R_{5}\right)\right]$. Будемо уважати, що опір навантаження $\left(\mathrm{RH}_{\mathrm{H}}\right)$ набагато більший, ніж опір резистора R1.

Друга проблема полягає в тому, що при виборі резисторів дільника з малим опором струм дільника буде великим і втрати енергії на нагрівання резисторів будуть значними.

Збільшувати опір резистора R1 можна тільки в таких межах поки його значення буде 
набагато менше ніж вхідний опір каскадів, що підключені після обмежувача.

Отже, залишається прийнятним тільки один шлях - зменшити еквівалентний опір дільника напруги. I в цьому випадку потрібно розглянути два випадки. Перший, коли вхідний сигнал подається на вхід обмежувача через розділовий конденсатор, і другий, коли на вхід обмежувача може подаватися постійна напруга або сигнал дуже низької частоти, значення якого перевищує допустиме для роботи пристрою значення.

Якщо треба обмежувати тільки змінну напругу, то можна підключити паралельно дільникам напруги конденсатори великої ємності. На рис. 3 це конденсатори С1 та С2, що підключаються між виходами дільників напруги і загальним проводом за допомогою ключів J1 та J2. Оскільки ємнісний опір конденсатора $x_{c}=1 / 2 \pi f C$, де $f$ - частота сигналу, а $C$ ємність конденсатора, може бути значно меншим, ніж опір резистора R1, то ефективність обмеження може бути високою. Для номіналів елементів, вказаних на рис. 3, опір конденсатора на частоті 1 кГц дорівнює 1,6 Ом, а на частоті 10 Гц - 160 Ом.

На рис. 4 наведені осцилограми сигналів на виході обмежувача за відсутності конденсаторів (рис. 4, а) та при під’єднаних конденсаторах при частоті сигналу 1000 Гц (рис. 4, б) і при частоті 10 Гц (рис. 4, в). 3 аналізу сигналів випливає, що під’єднання конденсаторів значно підвищує ефективність обмеження, але за обраної ємності С1 та С2 на частоті 10 Гц внутрішній опір дільника напруги стає настільки великим, що напруга на виході обмежувача перевищує задане значення.

Збільшення ємності конденсаторів дозволить розширити діапазон в область більш низьких частот. Але для обмеження постійної напруги такий шлях неприйнятний.

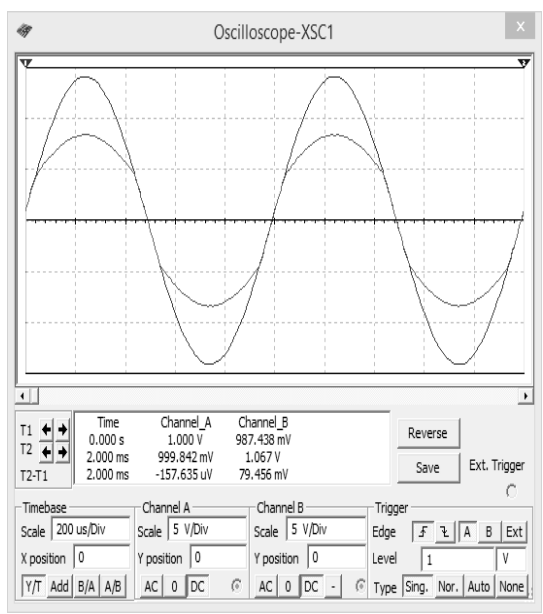

a)

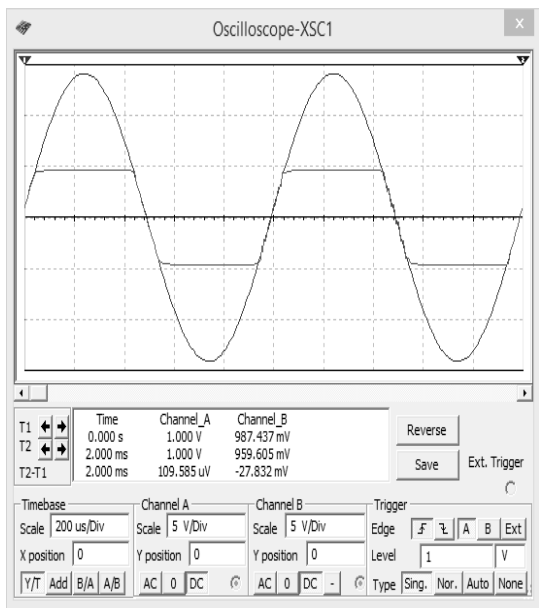

б)

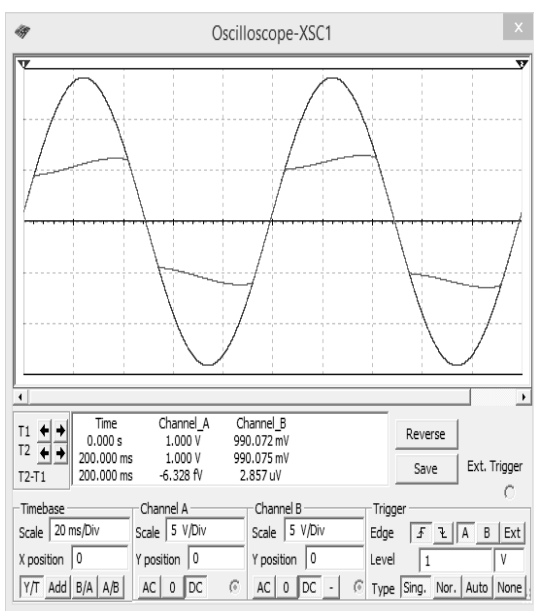

в)

Рис. 4. Осцилограми сигналів на виході обмежувача за відсутності конденсаторів (а), pf наявності конденсаторів на частоті сигналу 1000 Гц (б) та частоті сигналу 10 Гц (в)

Отже, потрібно замінити конденсатор елементом, опір якого як змінному так і постійному струму малий. Таким елементом $є$ стабілітрон. На рис. 5, а наведено схему обмежувача, у якому формування опорної напруги здійснюється за допомогою параметричних стабілізаторів напруги. 


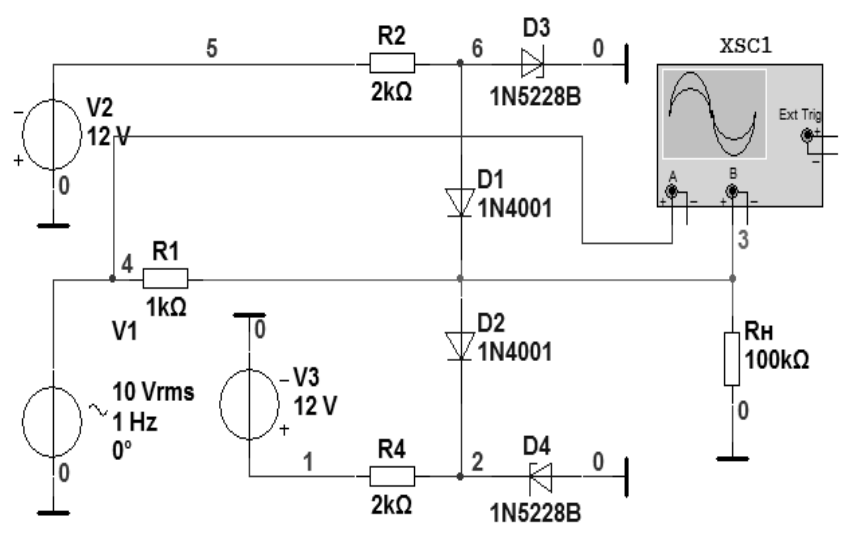

a)

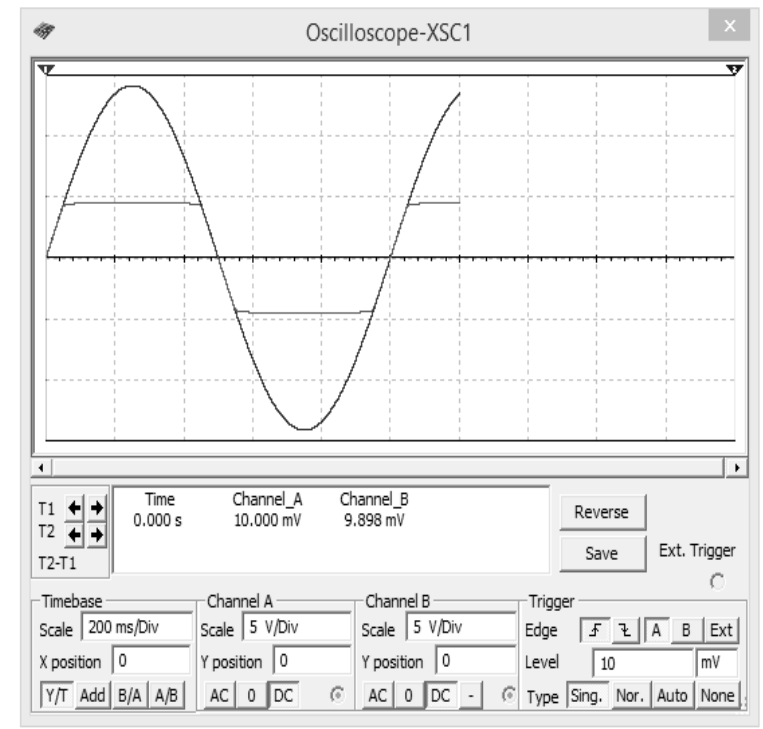

б)

Рис. 5. Схема обмежувача 3 формуванням опорної напруги за допомогою параметричного стабілізатора напруги (а) та осцилограма сигналу на виході обмежувача при частоті сигналу 1 Гц (б)

Стабілізатори складаються з резисторів R2, R4 та стабілітронів D3, D4, напруга стабілізації яких дорівнює 3,9 В. Оскільки внутрішній опір стабілітронів не перевищує десяти Ом, то таке джерело опорної напруги повинне забезпечити однаково ефективну роботу в діапазоні частот від постійного струму до 10 МГц, а при використанні більш високочастотних діодів 1N5228B - до частоти 60 МГц.

Отже, використовуючи програми моделювання, можна пояснити, як впливають окремі параметри елементів схем на результати роботи. У процесі пояснення можна замінювати елементи схеми, змінювати параметри сигналів і одразу демонструвати результати на екрані осцилографа або інших вимірювальних пристроїв. Використання таких програм у процесі навчання дозволяє давати індивідуальні завдання для самостійної роботи студентів. Під час виконання таких завдань студенти можуть контролювати правильність їх виконання. Використання програм моделювання в процесі навчання розширює можливості пізнання тонкощів роботи електронних пристроїв при мінімальних затратах часу.

\section{Література}

1. Макаренко В. В. Моделирование радиоэлектронных устройств с помощью программы NI Multisim [Електронний ресурс]/ В. В. Макаренко // Радиоежегодник : [Электронный журнал]. - 2013. - Выпуск : апрель (23). - С. 141-267. - Режим доступу до журн. : http:/www.rlocman.ru/book/book.html?di=148191. 2. Макаренко В. В. Программа моделирования Multisim Blue и ее основные возможности / В. В. Макаренко // Электронные компоненты и системы. - 2014. - № 10. - С. 25-32. 3. Цифрова та імпульсна схемотехніка. Моделювання та аналіз : [навч. посіб.] / В. В. Макаренко, В. М. Співак. - Київ : НТУУ «КПІ», 2015. - 280 c. 